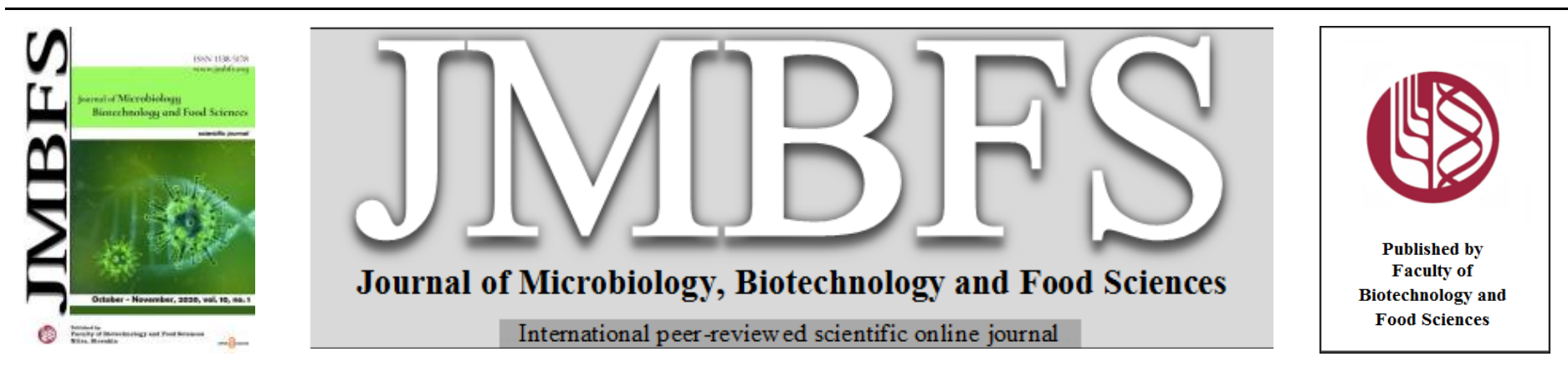

\title{
PATHOLOGICAL, BIOCHEMICAL AND MOLECULAR CHARACTERIZATION OF THE SEED-BORNE BACTERIA "PANTOEA SPP., XANTHOMONAS SPP. AND PSEUDOMONAS SPP." FROM SOLANACEOUS PLANTS IN EGYPT
}

\author{
Nader A. Ashmawyl, Alia A. Shoeib ${ }^{l}$, Hanan F. B. Youssef ${ }^{2}$ and Said M. Mahmoud ${ }^{2}$
}

\section{Address(es):}

${ }^{1}$ Plant Pathology Department, Faculty of Agriculture, Alexandria University, Egypt.

${ }^{2}$ Plant Protection Institute, Agricultural Research Center (ARC), Egypt.

*Corresponding author: nader_pcr@yahoo.com

doi: 10.15414/jmbfs.2020.10.2.289-295

\section{ARTICLE INFO}

Received 23. 8. 2019

Revised 12. 6. 2020

Accepted 29. 6. 2020

Published 1. 10. 2020

Regular article OPEN ${ }_{\text {ACCESS }}$

\begin{abstract}
The seed-borne bacterial diseases of family solanaceae cause significant economic losses worldwide. In the present study, fourteen bacterial isolates were recovered from seeds of different varieties of tomato, eggplant, black nightshade and tobacco. The seed samples were collected from different locations in Egypt. Isolated bacteria were identified based on morphological, physiological and biochemical tests as well as colonial morphology aspects on the differential medium, yeast extract dextrose calcium carbonate (YDC) besides the selective media (PA 20, King's B and Tween B). Pathogenicity of the isolated bacteria was assessed for causing graywall, bacterial speck and bacterial spot symptoms on tomato seedlings. Disease symptoms were recognized on leaves and stems of the inoculated seedlings. Re-isolation from collected seeds of the inoculated tomato plants was performed. Results indicated that Pantoea spp. was an endophytic bacteria, Pseudomonas spp. was an epiphytic bacteria, while Xanthomonas spp. was both epiphytic and endophytic bacteria. Furthermore, cellular fatty acids composition were identified and quantified to give a profile for tested bacterial isolates. Moreover, the bacterial isolates were identified at the molecular level via PCR reactions utilizing the 16S rRNA gene. Partial DNA sequences were analyzed using BLAST tool revealed that the inferred 16S rRNA partial sequences of the 7 isolates showed similarity to Pantoea ananatis ( 3 isolates), Pseudomonas syringae pv. tomato ( 2 isolates) and Xanthomonas vesicatoria ( 2 isolates). To the best of our knowledge the bacterium associated with the graywall seems to be first report of $P$. ananatis isolated from tomato fruits and black nightshade seeds in Egypt.
\end{abstract}

Keywords: seed borne bacteria, solanaceae, fatty acids, 16S rRNA, PA20

\section{INTRODUCTION}

Seed production has been moved to semi-arid regions to escape seed-borne pathogens. Seed-borne bacterial diseases continue to be problematic and cause significant economic losses worldwide. Infested seeds are responsible for thereemergence of diseases of the past, movement of pathogens across international borders, or the introduction of diseases into new areas (Gitaitis andWalcott, 2007)

Family Solanaceae, included important economical, medicinal crops and weeds in the world. One of them is Tomato (Lycopersicon esculentum Mill.) which cultivated for its fruits, having economic importance for domestic consumption, export and food industries. Egypt ranks fifth in the world for tomato production, 6.62 million metric tons (FAO, 2018).

Tomato seeds are subjected to infection by bacterial seed-borne diseases such as graywall disease caused by Pantoea ananatis [formerly, Erwinia ananas] (Stall et al., 1970 and Boyle, 1994). The genus Pantoea is a diverse group of yellowpigmented, rod shaped Gram-negative bacteria in the family Enterobacteriaceae. Some of the first members were recognized as plant pathogens causing wilting, soft rot and necrosis in different host plants (Walterson and Stavrinides, 2015). $P$. ananatis causes disease symptoms in a wide range of economically important agricultural crops and forest tree species worldwide, which associated with plants as an epiphyte and endophyte bacteria (Coutinho and Venter, 2009 ; Gi Yoon Shin et al., 2019)

Moreover, bacterial speck disease of tomato which caused by Pseudomonas syringae pv. tomato can also reduce yield when it severely affects leaves early in the growing season. The diseases is developed due to high humidity and low night temperatures (Kolomiets et al., 2017) .The bacterium can be moved from plant to plant via splashing water or on hands and gardening tools causes a serious outbreak on tomato plants grown in commercial fields (Sahin, 2001; Shenge et al., 2010).

Bacterial spot of tomato, caused by Xanthomonas vesicatoria, is a potentially devastating disease that can lead to unmarketable fruit and even plant death. Bacterial spots can occur wherever tomatoes are grown, but are found most frequently in warm, wet climates, as well as in greenhouses (Shenge $\boldsymbol{e t}$ al., 2010; Kolomiets et al., 2017). The pathogens enter plants through natural openings (e.g., stomates), as well as through wounds. Disease development is favored by warm, wet weather. Wind-driven rain can contribute to more severe disease as the pathogens are splashed and spread to healthy leaves and fruit. The species-specific PCR assays, biochemical and serological analyses were used to identify the Xanthomonas species associated with bacterial leaf spot of tomato as diagnostic protocols for this disease (Manjula et al., 2017; Roach et al., 2018; Vancheva et al., 2018). Therefore, the present study was conducted to achieve the following objectives: to isolate the seed-borne bacterial pathogens from solanaceous plants collected from different locations in Egypt, to identify and characterize the isolated bacteria through cultural, biochemical tests and fatty acid profiling, as well as, molecular techniques through 16S rRNA gene sequences.

\section{MARERIALS AND METHODS}

\section{Sampling collection}

Seeds of different varieties of some selected vegetable crops and weeds which belonging to family Solanaceae were collected as following: 6 varieties of tomato seeds (Solanum esculentum) namely Castle Rock, Super strain B, Peto 86, Super Jakal, Gs 12 and local variety were purchased from local markets at Alexandria Governorate. Moreover, one tomato seed sample of Super Jakal variety was obtained from naturally infected fruits collected from Assiut Governorate. Two varieties of eggplant seeds ( $S$. melongena) namely local variety and Black Beauty, as well as, one local variety of pepper seeds (Capsicum annuum) were purchased from local markets at Alexandria Governorate. Seeds of datura (Datura stramonium and D. metel), tobacco (Nicotiana tabacum) and black nightshade (S. nigrum) were obtained from Plant Pathology Institute, Agricultural 
Research Center (ARC), Giza, Egypt. The above mentioned varieties were used for isolation trials.

\section{Isolation procedures}

Isolation and detection of presumptive bacterial isolates from the above mentioned seed varieties were carried out using either dilution plating of seed extracts on semi-selective media or direct seed plating methods, as well as, liquid assay (LA) method.

Symptomless and morphologically infected seed samples were divided into 2 groups (I, II) for isolation trials. In group I, seeds were non surface sterilized to detect epiphytic. In group II seeds were surface sterilized to detect only the endophytic bacteria. Then seeds were macerated in the phosphate buffer saline (PBS-Tween 20). All seed varieties in each group were incubated overnight for $14 \mathrm{hrs}$ at $4^{\circ} \mathrm{C}$ in the same buffer at a ratio of $3 \mathrm{~mL}$ of buffer to 1 gram of seeds (v:w). (www.wordseed.org/--/Tomato_Xanthomonas_spp_010).

Ten-fold serial dilutions of either seed suspension or its extracts in PBS buffer were prepared. The resultant dilutions $(0.1 \mathrm{~mL})$ was spread onto two sem selective media, PA 20 medium for isolation of Pantoea spp. (Goszczynskaet al., 2006) and Tween B medium for Xanthomonas spp.(McGuire et al., 1986 andGore and O'Garro, 1999). Colonies observed after $4-7$ days at $28^{\circ} \mathrm{C}$ were isolated and purified through the single colony isolation technique. Colonies were transferred on a yeast extract-dextrose- $\mathrm{CaCO}_{3}$ (YDC) medium (Gitaitiset al. 1991) for further identification. Cultures were kept on nutrient agar (NA) medium for further studies.

\section{Direct plating on semi-selective media and liquid assay methods}

These methods were used for detection of Pseudomonas spp. from non-surface sterilized seeds (Group I). In direct plating method, 100 seed of each variety were planted on King's B medium (King et al. 1954). Seeds were distributed in ten plates, 10 seeds in each plate then incubated at $28^{\circ} \mathrm{C}$ for $4-5$ days.

In liquid assay method, 0.1 gram of non-surface sterilized seeds of each variety was soaked in $10 \mathrm{~mL}$ sterile saline solution $(0.85 \% \mathrm{NaCl})$ for $24 \mathrm{hrs}$ at room temperature $25 \pm 2{ }^{\circ} \mathrm{C}$ then, $0.1 \mathrm{~mL}$ of the suspension aliquots were spread on King's B medium. Isolated colonies were transferred on YDC medium for further identification.

\section{Pathogenicity tests}

\section{Inoculation of tomato seedlings}

Pure cultures of $(\mathrm{P})$ and $(\mathrm{X})$ bacterial isolates were cultivated on NA medium for $48 \mathrm{hrs}$. at $28^{\circ} \mathrm{C}$, whereas, (Ps) isolates was cultivated on King's B (KB) medium for $48 \mathrm{hrs}$ at $28^{\circ} \mathrm{C}$. Bacterial cells were collected and suspended in sterile distilled water (SDW). In case of (P) isolates, bacterial suspension was adjusted to ca. 10 $\mathrm{CFU} / \mathrm{mL}$. Four weeks-old tomato seedlings (Alissa F1 variety) were inoculated by injecting bacterial suspension into the stem. Then, stem-inoculated plants were placed in plastic bags to increase the relative humidity $(\mathrm{RH})$ and maintained in a greenhouse. The development of symptoms was recorded after 15 days. In case of (Ps) and (X), bacterial suspensions (ca. $10^{8} \mathrm{CFU} / \mathrm{mL}$ ) were atomized with a hand-held sprayer until run-off. After inoculation, plants were placed in plastic bags and maintained in a greenhouse. Development of symptoms was observed daily (Milijasevic et al., 2009). Control plants were treated in a similar way using sterile water. All inoculation tests were replicated three times.

Inoculation of tomato fruits

Immature tomato fruits (Alissa F1 variety) were inoculated with the suspension of (P) isolates by injection the bacterial suspension (ca. $10^{7} \mathrm{CFU} / \mathrm{mL}$ ) into the fruits using sterile syringe. Disease symptoms were recorded after 14 days. Healthy fruits injected by sterile water were served as a control.

\section{Re-isolation from artificially infected tomato}

\section{Tomato Seedlings and fruits}

Re-isolation from tomato seedlings was performed after 6 weeks from artificial infection. Leaves and stems of infected tomato seedlings (Alissa F1variety) were gently washed with tap water, cut into small pieces and soaked into a few drops of SDW for $30 \mathrm{~min}$. The resultant suspension was streaked on nutrient agar (NA) medium. Bacterial spots and speck lesions were excised and surface sterilized by dipping in $70 \%$ ethanol for 2 seconds followed by two successive rinses in SDW. Lesions were crushed in $0.5 \mathrm{~mL}$ SDW, and the resultant suspension was streaked on NA medium. All inoculated plates were incubated for 3 days at $28^{\circ} \mathrm{C}$ and a single colony of the predominant colonies was selected and purified by repeated streaking on the same medium, then examined for further studies. Moreover, reisolation was performed from fruits showing disease symptoms as previously mentioned.

\section{Tomato seeds}

Re-isolation from seeds which collected from tomato fruits was performed after 9 weeks from artificial infection of tomato seedlings as previously described (ELMeneisy, 2005).

\section{Identification of bacterial isolates}

\section{Cultural, morphological, physiological and biochemical Tests}

Bacterial isolates were identified using cultural, morphological, physiological and biochemical characteristics, which were conducted by performing the standard tests (Abd-Alla, 2000; Brenner et al., 2005; Bradyet al., 2009; Deletoile et al., 2009 and Al-Saleh, 2011). The above mentioned tests were applied on the obtained bacterial isolates which included: cell shape, sporulation, motility, Gram staining, catalase, oxidase, starch hydrolysis, gelatin liquefaction, arginine dihydrolase, nitrate reduction, levan production and acid production from mannose, cellobiose, mannitol and sorbitol.

Cultural characteristics of the bacterial isolates were studied on different culture media such as PA 20 medium for Pantoea spp., King's B medium for Pseudomonas spp. and Tween B medium for Xanthomonas spp., glycerol agar, NA and YDC media were used, also bacterial growth of Pseudomonas spp. and Xanthomonas spp. isolates was tested on PA 20 medium (Goszczynska et al., 2006a).

\section{Fatty acids analysis}

\section{Extraction of total cellular lipids}

Total lipids were extracted from seven bactrerial isolates grown on NB medium for $48 \mathrm{hrs}$ as described by Kates (1972). Bacterial cells were harvested after growth for $24 \mathrm{hrs}$ at room temperature with occasional shaking by centrifugation at $3000 \mathrm{~g}$ for $10 \mathrm{~min}$. Bacterial pellet $(0.5 \mathrm{~g})$ was transferred to screw cape tube capacity $20 \mathrm{~mL}$ and extracted with $5 \mathrm{~mL}$ methanol-chloroform mixture $(2: 1 \mathrm{v} / \mathrm{w})$ The organic layer was transferred to another tube, and $5 \mathrm{ml}$ of methanolchloroform mixture was added to re-extract the pellet for $2 \mathrm{hrs}$.

The organic solvent was decanted and collected to the first extract $2.5 \mathrm{~mL}$ chloroform and $2.5 \mathrm{~mL}$ of distilled water were add to each tube, mixed well, and left for phases separation. The chloroform lower layer containing total lipids was withdrawn into a screw cape tube $20 \mathrm{~mL}$ capacity. Chloroform was evaporated at $40^{\circ} \mathrm{C}$ under stream of nitrogen and the traces of water were removed by drops of benzene. Total lipids extract was kept refrigerated under nitrogen $\left(\mathrm{N}_{2}\right)$ gas.

\section{Preparation of methyl esters of fatty acids}

The methyl esters of fatty acids (MEsFA) were prepared from total lipids as described by Radwan (1978). The total lipids extract in the screw cape tube was dissolved in $2.0 \mathrm{~mL}$ benzene and $10 \mathrm{~mL}$ of the esterification reagent $(1 \%$ sulphuric acid in absolute methanol) were added. The tubes were caped under nitrogen and heated at $90^{\circ} \mathrm{C}$ for 90 minutes. Ten $\mathrm{mL}$ of distilled water were added to the cooled tubes and the MEsFA were extracted with $5 \mathrm{~mL}$ benzene and the extracts were dried using anhydrous sodium sulfate $(5 \mathrm{~g})$, received in $10 \mathrm{~mL}$ capacity vials, kept under $\mathrm{N}_{2}$ and used for gas liquid chromatography (GLC) analysis.

\section{Gas liquid chromatography of MEsFA}

The MEsFA were analyzed using Shimadzu-8 A, GLC equipped with flam ionization detector and ordinary glass column (ID $3 \mathrm{~mm} \mathrm{X} 2.5 \mathrm{~m}$.) of $5 \%$ diethylene glycol succinate on chromosorb Q 80/100 mesh. The following conditions were used for GLC analysis:column temperature $160^{\circ} \mathrm{C}$, detector temperature $270^{\circ} \mathrm{C}$, flow rates of nitrogen $20 \mathrm{~mL} / \mathrm{min}, \mathrm{H}_{2} 75 \mathrm{~mL} / \mathrm{min}$, air 0.5 $\mathrm{mL} / \mathrm{min}$, chart speed $2.5 \mathrm{~mm} / \mathrm{min}$. Standard MEsFA and their retention times were used for identification. The area under each peak was measured by the triangulation methods and expressed as percentage of each fatty acid with regard to the total area.

\section{Molecular identification}

\section{Extraction of genomic DNA}

Bacterial genomic DNA was extracted by boiling one $\mathrm{mL}$ of a suspension containing ca. $1 \times 10^{10} \mathrm{CFU} / \mathrm{mL}$ for $10 \mathrm{~min}$. DNA was separated by centrifugation for $5 \mathrm{~min}$ at $11.000 \mathrm{xg}$ (Yahiaoui-Zaidiet al.,2003).

\section{PCR amplification of 16S rRNA gene}

Full length $(1550 \mathrm{bp})$ of 16S rRNA gene was amplified from 3 isolates of Pantoea spp. $\left(\mathrm{P}_{1}, \mathrm{P}_{2}\right.$ and $\left.\mathrm{P}_{3}\right), 2$ isolates of Pseudomonas spp. $\left(\mathrm{Ps}_{\mathbf{1}}\right.$ and $\left.\mathrm{Ps}_{2}\right)$, and 2 isolates of Xanthomonas spp. $\left(\mathrm{X}_{1}\right.$ and $\left.\mathrm{X}_{2}\right)$ using the universal primers $\mathrm{P} 0(\mathrm{~F})$ 
(5'GAAGAGTTTGATCCTGGCTCAG3'),

P6(R)

(5'CTACGGCTACCTTGTGTTACGA3'). PCR amplification was carried out in a total volume $50 \mu \mathrm{L}$ containing $5 \mu \mathrm{L} 10$ x buffer, $4 \mu \mathrm{L} 25 \mathrm{mM} \mathrm{MgCl}_{2}, 4$ $\mu \mathrm{L} 2.5 \mathrm{mMdNTPs}, 2 \mu \mathrm{L} 10 \mathrm{pmol}$ forward primer, $2 \mu \mathrm{L} 10 \mathrm{pmol}$ reverse primer, 2 $\mu \mathrm{L} 50 \mathrm{ng}$ of bacterial genomic DNA and $0.4 \mu \mathrm{L}$ (5 units/ $\mu \mathrm{L}$ ) Taq DNA polymerase - Promega, Germany. PCR amplification was performed in a thermal cycler (Techne,UK) programmed for one cycle at $95^{\circ} \mathrm{C}$ for $5 \mathrm{~min}$ followed by 34 cycles each with $45 \mathrm{~s}$ at $95^{\circ} \mathrm{C}$ for denaturation, $1 \mathrm{~min}$ at $50^{\circ} \mathrm{C}$ for annealing and 2 min at $72^{\circ} \mathrm{C}$ for elongation. Reaction mixture was then incubated at $72^{\circ} \mathrm{C}$ for 10 min for final extension (Ashmawy et al., 2015).

\section{PCR product of electrophoresis and visualization}

Two $\mu \mathrm{L}$ of loading dye was added prior to loading of $10 \mu \mathrm{l}$ per gel slot. Electrophoresis was performed at 100 volt with $0.5 \mathrm{x}$ Tris-EDTA-borate (TBE) (Tris base, $108 \mathrm{~g} / \mathrm{L}$ boric acid, $55 \mathrm{~g} / \mathrm{L}$ and $0.5 \mathrm{M}$ EDTA with a $\mathrm{pH}$ of $8,40 \mathrm{ml}$ for $10 \mathrm{x}$ ) as running buffer in $1.5 \%$ agarose gel cast in $0.5 \mathrm{x}$ TBE gel and then the gel was stained in $0.5 \mu \mathrm{g} / \mathrm{mL}(\mathrm{w} / \mathrm{v})$ ethidium bromide solution and distained in deionized water. Finally, the gel was visualized with a UV transilluminator at 254 nm.

\section{Purification of PCR products}

QIAquick PCR purification kit (Qiagen, Germany) was used to purify the amplified products of $16 \mathrm{~S}$ rRNA gene.

\section{Sequencing of 16S rRNA gene}

The amplified product (1550 bp) of 16S rRNA was sequenced by Big Dye terminator cycle sequencing kit. Sequencing products were purified using CentriSep spin columns and were resolved on an ABIPRISM model 310 automated DNA sequencer at the Sigma Scientific Services Company.

\section{Alignment and phylogenetic analysis}

Pair-wise and multiple DNA sequence alignment were carried out using CLUSTALW (1.82) http://www.ebi.ac.uk/clustalw . Bootstrap neighbor-joining tree generated using MEGA version 7.0 (Kumar et al., 2016) from CLUSTALW alignment. Comparisons with sequences in the GenBank database were achieved in BLASTN searches at the National Center for Biotechnology Information site (http://www.ncbi.nlm.nih.gov). The obtained sequences in the current study were deposited in European Nucleotide Archive (ENA) under accession numbers from LN880270 to LN880276.

\section{RESULTS}

\section{Isolation trials from collected seeds}

Seed samples of different varieties of tomato, eggplant, tobacco, black nightshade, pepper and datura were collected in this study. Only one seed sample was obtained from naturally infected tomato fruits (Super jakal variety) showed typical symptoms of gray wall disease.

Different bacterial colonies were observed on glycerol agar, nutrient agar, yeast extract dextrose-CaCo3 (YDC), as well as, semi selective media, PA20, King's B and Tween B (Table 1). According to their colonies characteristics on the previous semi selective media, three types of bacterial isolates were detected: Type I [typical colonies of Pantoea spp. $\left(\mathrm{P}_{1}, \mathrm{P}_{2}, \mathrm{P}_{3}, \mathrm{P}_{4}\right.$ and $\left.\mathrm{P}_{5}\right)$ ] on PA20 medium, colonies were yellow, 3-4 $\mathrm{mm}$ in diameter, shiny, drop shaped with small, granular, darker inclusions inside and yellow lighter zones around colonies, Type II [Typical colonies of Pseudomonas spp. $\left(\mathrm{Ps}_{1}, \mathrm{Ps}_{2}, \mathrm{Ps}_{3}, \mathrm{Ps}_{4}, \mathrm{Ps}_{5}\right.$ and $\left.\mathrm{P}_{6}\right)$ ] on King's $B$ medium, colonies were white, circular and mucoid and Type III [typical colonies of Xanthomonas spp. $\left(\mathrm{X}_{1}, \mathrm{X}_{2}\right.$ and $\left.\mathrm{X}_{3}\right)$ ] on Tween B medium, colonies were raised, circular and yellow surrounded by zones of white crystals giving a fried-egg appearance (Fig.1).

\section{Pathogenicity tests}

\section{Tomato seedlings}

All the bacterial isolates Type $\mathrm{I}\left(\mathrm{P}_{1}, \mathrm{P}_{2}, \mathrm{P}_{3}, \mathrm{P}_{4}\right.$ and $\left.\mathrm{P}_{5}\right)$, Type II $\left(\mathrm{Ps}_{1}, \mathrm{Ps}_{2}, \mathrm{Ps}_{3}, \mathrm{Ps}_{4}\right.$ $\mathrm{Ps}_{5}$ and $\left.\mathrm{P}_{6}\right)$ and Type III $\left(\mathrm{X}_{1}, \mathrm{X}_{2}\right.$ and $\left.\mathrm{X}_{3}\right)$ were tested for their pathogenicity on tomato seedlings Alissa F1 and Gs Nada varieties. Inoculation with isolates of type I, stems appeared shrivel and wither, moreover, discolored water-conducting tissue and chlorosis was appeared on leaves (Figs. 2) which were suspected to belong to Pantoea spp. Inoculation with isolates of type II showed necrotic spots surrounded by a chlorotic halo appearing on leaves (Fig. 3) which were suspected to belong to Pseudomonas spp. In case of inoculation with type III bacterial isolates, leaves appeared water soaked lesions and became brown color (Fig. 4) which was suspected to belong to Xanthomonas spp.
Table 1 Isolates and colony type of seed-borne bacteria isolated from different seed cultivars on semi-selective media

\begin{tabular}{|c|c|c|c|}
\hline Seed samples & Media & Colony type & Isolate code \\
\hline \multicolumn{4}{|c|}{ Tomato cultivars } \\
\hline Castle rock & PA 20 & $I^{*}$ & $\mathrm{P}_{4}$ \\
\hline Super strain B & King's B & II & $\mathrm{Ps}_{1}$ \\
\hline Peto 86 & Tween B & III & $\mathrm{X}_{1}, \mathrm{X}_{2}$ \\
\hline \multirow[t]{2}{*}{ Gs 12} & $\begin{array}{l}\text { King's B - } \\
\text { Tween B }\end{array}$ & II-III & $\mathrm{Ps}_{2}, \mathrm{X}_{3}$ \\
\hline & PA 20 & I & $\mathrm{P}_{2}$ \\
\hline \multirow[t]{2}{*}{ Local variety 1} & King's B & - & - \\
\hline & Tween B & - & - \\
\hline \multirow[t]{3}{*}{ Local variety 2} & PA 20 & - & - \\
\hline & King's B & - & - \\
\hline & Tween B & - & - \\
\hline Super jakal & PA 20 & I & $\mathrm{P}_{1}$ \\
\hline \multicolumn{4}{|c|}{ Eggplant cultivars } \\
\hline \multirow[t]{2}{*}{ Black beauty } & King's B & II & $\mathrm{Ps}_{3}, \mathrm{Ps}_{4}, \mathrm{Ps}_{5}, \mathrm{Ps}_{6}$ \\
\hline & PA 20 & - & - \\
\hline \multirow[t]{2}{*}{ Local variety } & King's B & - & - \\
\hline & Tween B & - & - \\
\hline Black nightshade & PA 20 & I & $\mathrm{P}_{3}$ \\
\hline Tobacco & PA 20 & $\mathrm{I}$ & $\mathrm{P}_{5}$ \\
\hline \multicolumn{4}{|c|}{ Pepper cultivar } \\
\hline \multirow{3}{*}{ (Local variety) } & PA 20 & - & - \\
\hline & King's B & - & - \\
\hline & Tween B & - & - \\
\hline \multicolumn{4}{|c|}{ Datura } \\
\hline & PA 20 & - & - \\
\hline & King's B & - & - \\
\hline & Tween B & - & - \\
\hline
\end{tabular}
white colonies, circular and mucoid and Type III, yellow colonies surrounded by zones of white crystals. (-), no colonies were detected.

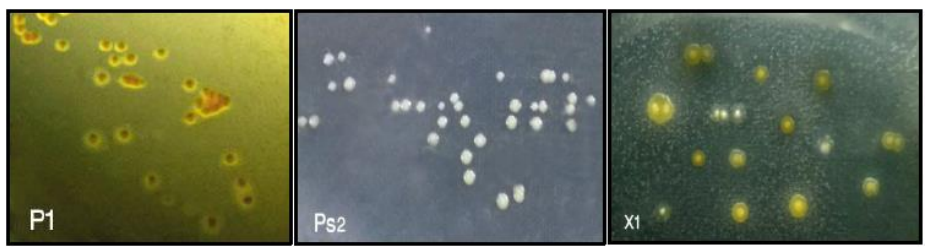

Figure 1 Typical colonies of Pantoea spp. ( $\mathrm{P}_{1}$ isolate) on PA 20 medium, Pseudomonas spp. ( $\mathrm{Ps}_{2}$ isolate) on King's B medium and Xanthomonas spp. $\left(\mathrm{X}_{1}\right.$ isolate) on Tween B medium.

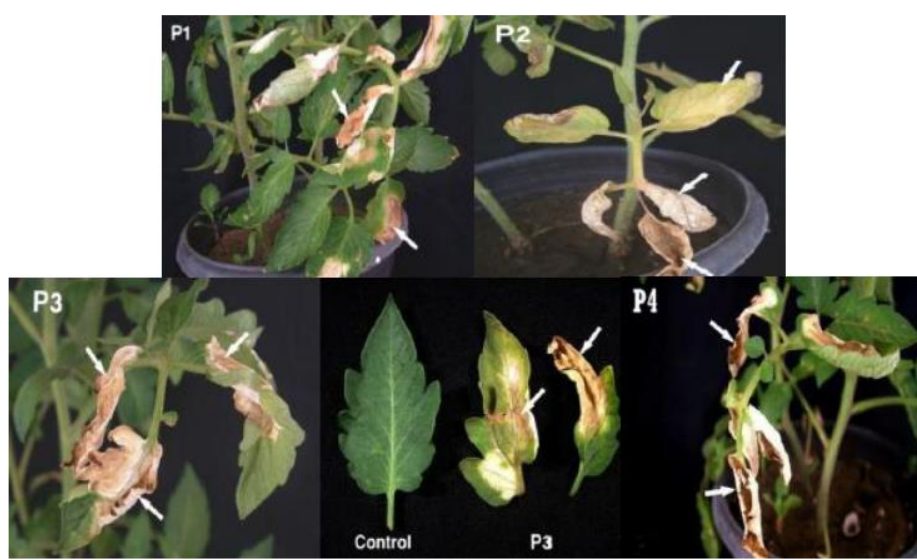

Figure 2 Artificially infected tomato seedlings "Alissa F1" with Type I isolates $\left(\mathrm{P}_{1}, \mathrm{P}_{2}, \mathrm{P}_{3}\right.$ and $\left.\mathrm{P}_{4}\right)$ of Pantoea spp. Showing yellowness on leaves (arrows).

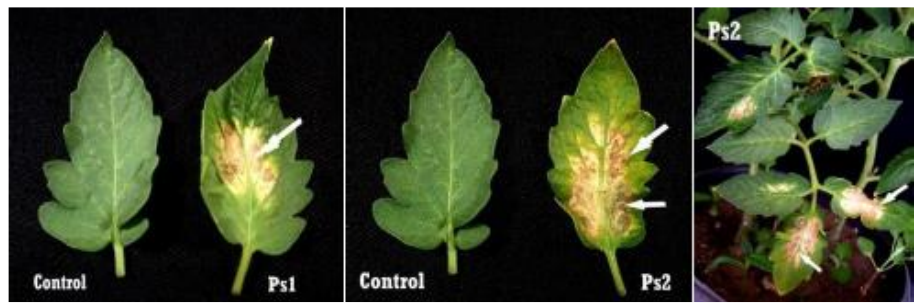

Figure 3 Artificially infected tomato seedlings "Alissa F1" with Type II isolates $\left(\mathrm{Ps}_{1}\right.$ and $\left.\mathrm{Ps}_{2}\right)$ of Pseudomonas spp. showing necrotic spots surrounded by a chlorotic halo appearing on leaves (arrows). 


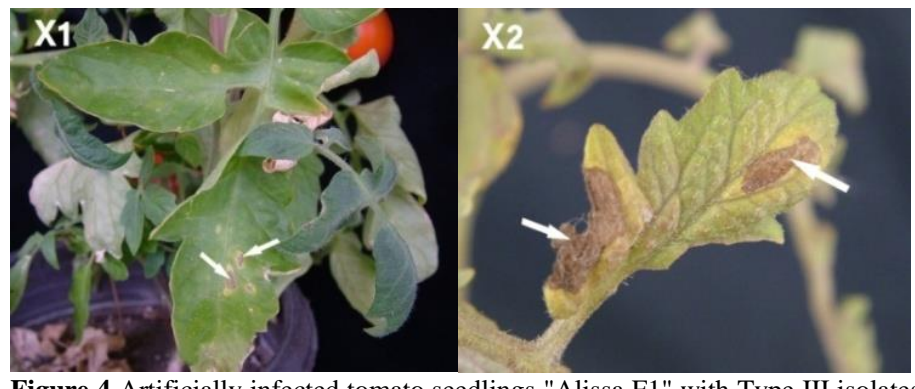

Figure 4 Artificially infected tomato seedlings "Alissa F1" with Type III isolate $\left(\mathrm{X}_{1}\right.$ and $\left.\mathrm{X}_{2}\right)$ of Xanthomonas spp. showing water soaked lesions on leaves which became brown colour (arrows).

\section{Tomato fruits}

All isolates of Pantoea spp. (P) were tested for their pathogenicity on tomato fruits (Alissa F1) and showed grey areas around the inoculation site (Fig. 5).

\section{Re-isolation from artificially infected seedlings}

\section{Tomato seedlings and fruits}

Re-isolation from infected seedlings with isolated bacteria appeared identical to those colonies of Pantoea spp., Pseudomonas spp. and Xanthomonas spp.

Re-isolation from inoculated fruits on selective media produced yellow colonies typical to Pantoea spp.

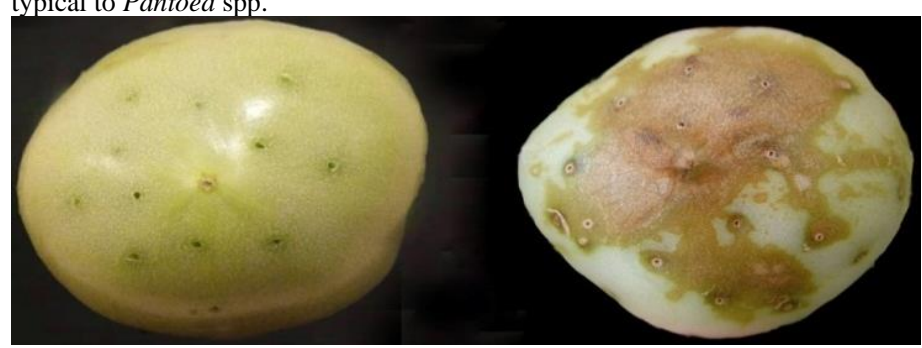

Figure 5 Artificially infection of tomato fruits "Alissa F1" with type I (P3) isolate of Pantoea spp. showed typical graywall symptoms (right), compared with control treatment (left)

\section{Tomato seeds}

Re-isolation from non-surface sterilized seeds from infected seedlings with $\mathrm{P}$ isolate appeared typical graywall disease symptoms didn't revealed colonies identical to Panteoa spp. Otherwise non surface-sterilized seeds from infected seedlings with Ps 2 isolate and X3 isolate showed typical bacterial speck and spot diseases symptoms and produced colonies identical to Pseudomonas spp. and Xanthomonas spp. respectively.

Re-isolation from macerated surface-sterilized seeds revealed colonies identical to Pantoea spp. ( $\mathrm{P}_{1}$ isolate) and Xanthomonas spp. ( $\mathrm{X}_{1}$ isolate), otherwise didn't revealed colonies identical to Pseudomonas spp. ( $\mathrm{Ps}_{2}$ isolate).

Table 2 Morphological traits, physiological and biochemical tests of Pantoed spp.(P, type I), Pseudomonas spp. (Ps, type II) and Xanthomonasspp.(X, type III)

\begin{tabular}{lccc}
\hline Characteristics & $\begin{array}{c}\text { Pantoea spp. } \\
\text { (Type I) }\end{array}$ & $\begin{array}{c}\text { Pseudomons spp. } \\
\text { (Type II) }\end{array}$ & $\begin{array}{c}\text { Xanthomonas spp. } \\
\text { (Type III) }\end{array}$ \\
\hline Cell shape & short rods & short rods & short rods
\end{tabular}

\begin{tabular}{|c|c|c|c|}
\hline Cell shape & short rods & short rods & short rods \\
\hline Gram Stain & - & - & - \\
\hline
\end{tabular}

Spore formation

Growth at $36^{\circ} \mathrm{C}$

Growth at $4^{\circ} \mathrm{C}$

Motility

Catalase production

Oxidase activity

Hydrolysis of: Starch

Casein

Gelatine

Urea

Lipid (Lipase activity)

Arginine dehydrolase

Nitrate reduction

Levan production

Acid production from:

Mannitol, Mannose, Sorbitol,

Cellobiose

Growth in the presence of:

$\mathrm{NaCl} 4 \%$

Streptomycin $(10 \mu \mathrm{g})$

Pathogenicity

$+=$ Positive reaction $\quad-=$ Negative reaction

\section{Identification of the seed borne bacterial isolates}

Isolation process revealed three types of bacteria, type I, II and III which were short rods and non-spore formers and Gram Negative (Table 2). Data presented in Table (2) showed that all tested bacterial isolates Pantoea spp.(P, type I), Pseudomonas spp.(Ps, type II) and Xanthomonas spp. (X, type III) were positive for catalase, gelatin hydrolysis, levan production, negative for oxidase, starch hydrolysis, arginine dihydrolase and nitrate reduction. Whereas, all isolates were positive for acid production of mannitol, mannose, sorbitol and cellobiose. Some tests were revealed differentiation in their reaction among tested isolates.

Data presented in Table (3) and Figs. (6, 7 and 8) showed differences among colonies characteristics of Pantoea spp. (P, type I), Pseudomonas spp. (Ps, type II) and Xanthomonas spp.(X, type III) on different culture media.

Tested isolates of Pseudomonas spp. and Xanthomonas spp. couldn't grow on PA 20 medium compared with Pantoea spp. (Fig. 9).

Table 3 Colonial characteristics of Pantoea spp. (P, type I), Pseudomonas spp (Ps, type II) and Xanthomonas spp. (X, type III) on different culture media

\begin{tabular}{|c|c|c|c|}
\hline Media & $\begin{array}{c}\text { Pantoea spp. } \\
\text { (Type I) }\end{array}$ & $\begin{array}{l}\text { Pseudomons } \\
\text { spp. } \\
\text { (Type II) }\end{array}$ & $\begin{array}{c}\text { Xanthomonas } \\
\text { spp. } \\
\text { (Type III) }\end{array}$ \\
\hline Glycerol agar & $\begin{array}{l}\text { Yellow, } \\
\text { circular and } \\
\text { smooth }\end{array}$ & $\begin{array}{c}\text { Beige, } \\
\text { circular and } \\
\text { smooth }\end{array}$ & $\begin{array}{l}\text { Yellow, } \\
\text { circular and } \\
\text { mucoid }\end{array}$ \\
\hline Nutrient agar & $\begin{array}{l}\text { Pale yellow, } \\
\text { smooth and } \\
\text { translucent }\end{array}$ & $\begin{array}{l}\text { White, } \\
\text { circular and } \\
\text { smooth }\end{array}$ & $\begin{array}{l}\text { Pale yellow } \\
\text { circular and } \\
\text { smooth }\end{array}$ \\
\hline $\begin{array}{l}\text { Yeast extract } \\
\text { dextrose-CaCo3 } \\
\text { (YDC) }\end{array}$ & $\begin{array}{l}\text { Yellow,regularly } \\
\text { round and } \\
\text { mucoid } \\
\text { surrounded by } \\
\text { clear ring }\end{array}$ & $\begin{array}{l}\text { White,circula } \\
\text { r, domed } \\
\text { and smooth }\end{array}$ & $\begin{array}{c}\text { Yellow, } \\
\text { circular, } \\
\text { smooth, domed } \\
\text { and mucoid - } \\
\text { fluidal } \\
\text { surrounded } \\
\text { byclear ring }\end{array}$ \\
\hline PA 20 & $\begin{array}{l}\text { Yellow, 3-4 mm } \\
\text { in diameter, } \\
\text { shiny drop } \\
\text { shaped with } \\
\text { small, granular } \\
\text { and darker } \\
\text { inclusions inside }\end{array}$ & - & - \\
\hline
\end{tabular}

urrounded with

Tween B halo, raised and circular

white, circular and mucoid

\section{$(-)=$ No growth}

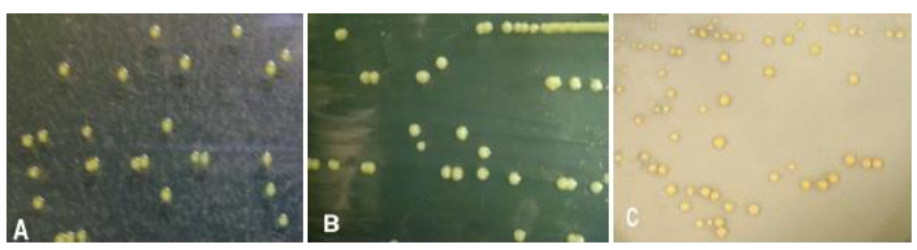

Figure 6 Typical colonies of Pantoea spp. (P, Type I) on Glycerol Agar (A) Nutrient Agar (B) and Yeast Extract Dextrose calcium carbonate agar (C).
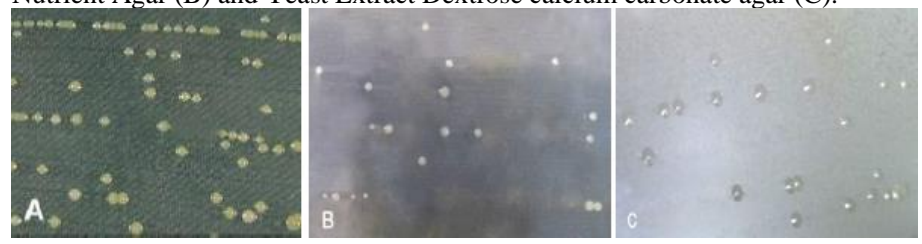

Figure 7 Typical colonies of Pseudomonas spp. (Ps, type II) on Glycerol Aga (A), Nutrient Agar (B) and Yeast Extract Dextrose calcium carbonate agar (YDC) (C).
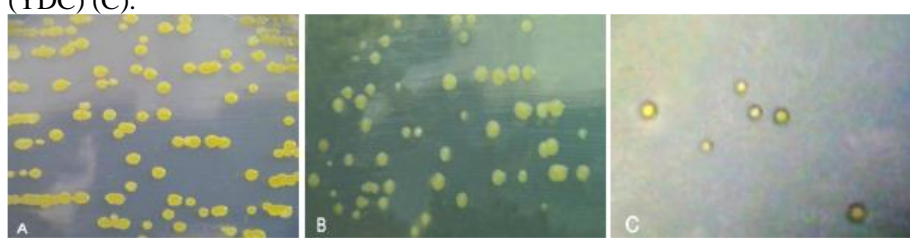

Figure 8 Typical colonies of Xanthomonas spp (X, type III) on Glycerol Agar (A), Nutrient Agar (B) and Yeast Extract Dextrose calcium carbonate agar (YDC) (C). 


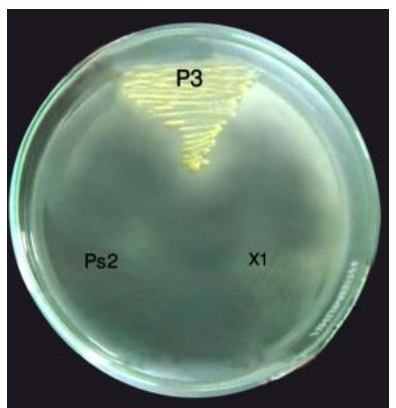

Figure 9 Bacterial growth of Pantoea spp. (P, Type I) on PA 20 selective medium. No growth appeared of Pseudomonas spp. (Ps, Type II) and Xanthomonas spp. (X, Type III) on PA 20 medium.

\section{Determination of cellular fatty acids composition}

Fatty acids methyl esters (FAMEs) were identified and quantified to give a profile for tested isolates. Cellular fatty acid contents of isolates of Pantoea spp. $\left(\mathrm{P}_{1}, \mathrm{P}_{2}, \mathrm{P}_{3}\right)$, Pseudomonas spp. $\left(\mathrm{Ps}_{1}, \mathrm{Ps}_{2}\right)$ and Xanthomonas spp. $\left(\mathrm{X}_{1}, \mathrm{X}_{2}\right)$ were determined and summarized in Table (4) as following:

The main data analyses of fatty acid compositions measured by percentage of total area of a fatty acid to all fatty acids in percentage $(\mathrm{P})$ were used to obtain the ratio between the fatty acids values. The considered method for explanation of the quantities and distribution of cellular fatty acids among all bacterial isolates, showed in presence of 18 fatty acids.

The major fatty acids detected in Pantoea spp. isolates were Dodecanoic (12:0),Tetradecanoic (14:0),Hexadecanoic (16:0) and Octadecanoic acids (18:0).whereas, the primary fatty acids found in Pseudomonas spp. isolates were Tetradecanoic (14:0) and Hexadecenoic acids (16:1). In case of Xanthomonas spp. isolates, the major fatty acids detected were Tetradecanoic(14:0), Pentadecanoic (15:0) and Hexadecanoic acids (16:0)

The fatty acids Tetradecenoic (14:1), Tetradecanoic (14:0) and Pentadecenoic (15:1) were found in of Pantoeaspp. $\left(\mathrm{P}_{1}\right)$, in high percentage $24.97 \%, 23.07 \%$ and $24.39 \%$ respectively, while these fatty acids were found in $\mathrm{P}_{2}$ and $\mathrm{P}_{3}$ isolates of Pantoea spp. in low percentage. The number of fatty acids found in of Pseudomonas spp. $\left(\mathrm{Ps}_{1}\right)$ were less than the number of fatty acids which found in Ps2 isolate.

The fatty acids Tridecanoic (13:0), Tetradecanoic (14:0) and Pentadecenoic (15:1) were found in Xanthomonas spp. $\left(\mathrm{X}_{1}\right)$ in high percentage 35.85\%, $23.06 \%$ and $26.78 \%$ in order given, while they were found in $\mathrm{X}_{2}$ isolate in low percentage $10.06 \%, 0.77 \%$ and $6.39 \%$ respectively. Tridecanoic acid (13:0) and Pentadecenoic acid $(15: 1)$ were found in all previous isolates. Undecanoic (11:0), Heptadecanoic (17:0), Linoleic (18:2c) and Eicosatrienoic acids (20:3w6) were absent in $\mathrm{P}_{1}, \mathrm{P}_{2}, \mathrm{P}_{3}, \mathrm{Ps}_{1}$ and $\mathrm{X}_{2}$ isolates, while they were detected in $\mathrm{Ps}_{2}$ and $\mathrm{X}_{1}$ isolates. Dodecanoic acid (12:0) and Octadecanoic acid (18:0) were found in all isolates except $\mathrm{Ps}_{1}$ and $\mathrm{X}_{1}$ isolates, respectively.

Table 4 Relative fatty acid compositions of tested bacterial isolates.

\begin{tabular}{|c|c|c|c|c|c|c|c|c|}
\hline \multicolumn{2}{|c|}{ Fatty acid(FAMEs) } & \multicolumn{7}{|c|}{ Bacterial isolates } \\
\hline \multirow{2}{*}{$\begin{array}{l}\text { Shorthand } \\
\text { designation }\end{array}$} & \multirow{2}{*}{ Systematic name } & $\mathbf{P}_{1}$ & $\mathbf{P}_{2}$ & $\mathbf{P}_{3}$ & $\mathbf{P s}_{1}$ & $\mathbf{P s}_{2}$ & $\mathbf{X}_{1}$ & $\mathbf{X}_{2}$ \\
\hline & & \multicolumn{7}{|c|}{ Fatty acids (\% of the total fatty acids) } \\
\hline C 11:0 & Undecanoic & - & - & - & - & 0.10 & 0.70 & - \\
\hline C $12: 0$ & Dodecanoic & 8.56 & 0.23 & 0.13 & - & 0.18 & 6.15 & 0.22 \\
\hline C $13: 0$ & Tridecanoic & 8.97 & 7.48 & 8.05 & 2.78 & 0.06 & 35.85 & 10.06 \\
\hline C $14: 1$ & Tetradecenoic & 24.97 & 4.27 & 4.95 & 1.60 & 6.32 & 22.45 & 5.74 \\
\hline C $14: 0$ & Tetradecanoic & 23.07 & 0.59 & 0.68 & 0.12 & 6.11 & 23.06 & 0.77 \\
\hline C $15: 1$ & Pentadecenoic & 24.39 & 3.88 & 5.28 & 1.64 & 6.63 & 26.78 & 6.39 \\
\hline C $15: 0$ & Pentadecanoic & 21.63 & 0.31 & - & - & 5.67 & 21.36 & 5.24 \\
\hline C $16: 1$ & Hexadecenoic & 10.20 & 0.23 & 0.12 & 0.51 & 2.91 & 2.01 & 0.93 \\
\hline C $16: 0$ & Hexadecanoic & 15.80 & 3.53 & 3.53 & - & 5.33 & 10.32 & 1.85 \\
\hline C $17: 1$ & Heptadecenoic & 3.77 & - & - & - & 0.09 & 0.57 & - \\
\hline C $17: 0$ & Heptadecanoic & - & - & - & - & 0.46 & 0.58 & - \\
\hline C $18: 3$ & Octadecatrienoic & - & - & - & - & 0.09 & 2.82 & 0.07 \\
\hline C $18: 2 \mathrm{c}$ & Linoleic & - & - & - & - & 0.61 & 1.66 & - \\
\hline C $18: 2 \mathrm{t}$ & Linolelaidic & 2.03 & 0.42 & - & 0.14 & 4.04 & - & 0.44 \\
\hline C $18: 1 \mathrm{c}$ & Vaccenic & - & - & 0.41 & - & - & 0.56 & - \\
\hline C $18: 1 \mathrm{t}$ & Octadecenoic & 5.57 & 1.09 & 0.51 & 0.19 & - & - & - \\
\hline C 18:0 & Octadecanoic & 1.53 & 0.37 & 0.39 & 0.14 & 1.27 & - & 0.51 \\
\hline C 20:3w6 & Eicosatrienoic & - & - & - & - & 0.13 & 3.96 & - \\
\hline
\end{tabular}

\section{Molecular identification through 16S rRNA gene}

The following partial sequences were obtained for Pantoea spp. isolates $\mathrm{P}_{1}, \mathrm{P}_{2}$ and $\mathrm{P}_{3}$,Psendomonas spp. isolates $\mathrm{Ps}_{1}, \mathrm{Ps}_{2}$ and Xanthomonas spp. isolates $\mathrm{X}_{1}$ and $\mathrm{X}_{2}$. Search in databases to identify the bacteria was achieved in BLAST search at the NCBI. The search revealed that the sequence corresponding to each individual isolate of $\mathrm{P}_{1}, \mathrm{P}_{2}$ and $\mathrm{P}_{3}$ was almost identical (99\% homology) to that of Pantoea ananatis whereas, the sequence of each of the Ps1 and $\mathrm{Ps}_{2}$ was almost similar to that of Psendomonas syringae pv. tomato. The Genbank accession numbers of the bacterial isolates were listed in Table (5). While the sequence of each of the $X_{1}$ and $X_{2}$ was almost similar (97\% homology) to that of Xanthomonas vesicatoria.

Table 5 Accession number of partial 16s rRNA gene of Pantoea ananatis, Pseudomonas syringe pv. tomato and Xanthomonas vesicatoria isolates in the GenBank

\begin{tabular}{|c|c|c|}
\hline Isolate code & Bacterial isolates & NRea6si8n.nGsroup II \\
\hline $\mathrm{P}_{1}$ & Pantoea ananatis & (LN\$88006)(6ig.12) \\
\hline $\mathrm{P}_{2}$ & Pantoea ananatis & LN880271 \\
\hline $\mathrm{P}_{3}$ & Pantoea ananatis & LN880272 \\
\hline $\mathrm{Ps}_{1}$ & Pseudomonas syringae pv. tomato & LN880273 \\
\hline $\mathrm{Ps}_{2}$ & Pseudomonas syringae pv. tomato & LN880274 \\
\hline$X_{1}$ & Xanthomonas vesicatoria & LN880275 \\
\hline $\mathrm{X}_{2}$ & Xanthomonas vesicatoria & LN880276 \\
\hline
\end{tabular}

\section{Alignment and phylogenetic analysis}

The phylogenetic tree generated in this study for the P.ananatis isolates $\mathrm{P}_{1}, \mathrm{P}_{2}$ and $\mathrm{P}_{3}$ revealed that two main clusters do exist. Cluster I included the two out- group isolates Pectobacterium carotovorum subsp. carotovorum "Pcc" (AB680280) and Erwinia tracheiphila "E.trach" (NR044924). Cluster II divided into two Sub-clusters: Sub-cluster 1 divided further into two Groups: Group 1 contained the two isolates of P.ananatis isolated from tomato $\mathrm{P}_{1}(\mathrm{LN} 880270)$ and $\mathrm{P}_{2}$ (LN880271) besides the P.ananatis isolates collected from Genbank. However, Group 2 included only one isolate $\mathrm{P}_{3}$ (LN880272) which isolated from Black nightshade. Sub-cluster 2 included only one isolate KJ670108 (Fig. 10)

While, the phylogenetic tree generated for the Pseudomonas syringae pv.tomato isolates revealed that two main clusters do exist. Cluster I contained our two isolates $\mathrm{Ps}_{1}$ (LN880273) and $\mathrm{Ps}_{2}$ (LN880274). Whereas Cluster II included the other isolatesof Ps. Syringae pv. tomato collected from Genbank (Fig.11).

In case of phylogenetic tree generated in this study for the Xanthomonas vesicatoria isolates revealed that two main clusters do exist. Cluster I included only one isolate KP84443. Cluster II divided into two Sub-clusters: Sub-cluster 1 divided further into two Groups: Group 1 contained the two isolates contained isolates collected from Genbank KU301883, HF585549, AF123088 and ARoessi8h.nGroup II included the two isolates $X_{1}$ (LN880275) and $X_{2}$

LN880275

LN880276 


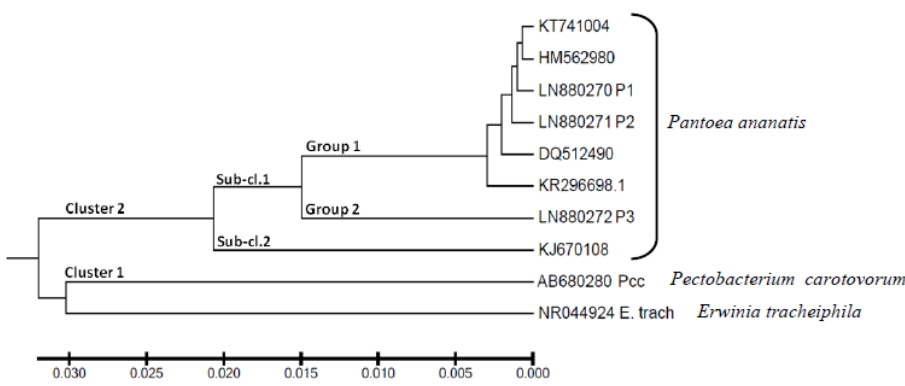

Figure 10 phylogenetic tree of Pantoea ananatis (P1, P2 and P3 isolates) obtained in this study and validly related bacteria from the alignment of $16 \mathrm{~S}$ rRNA sequences. The scale appearing at the bottom indicates linkage distance.

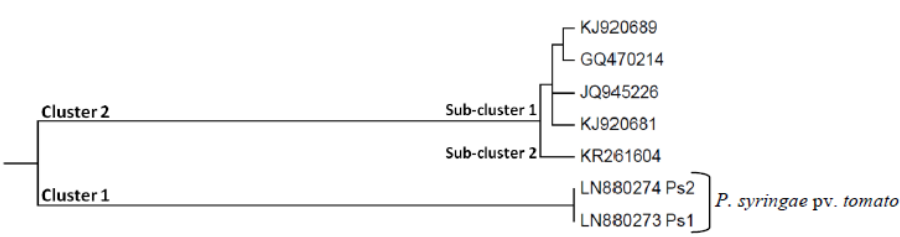

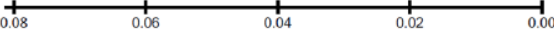

Figure 11 Phylogenetic tree of Pseudomonas syringae pv. tomato (Ps1 and Ps2 isolates) obtained in this study and validly related bacteria from the alignment of $16 \mathrm{~S}$ rRNA sequences. The scale appearing at the bottom indicates linkage distance.
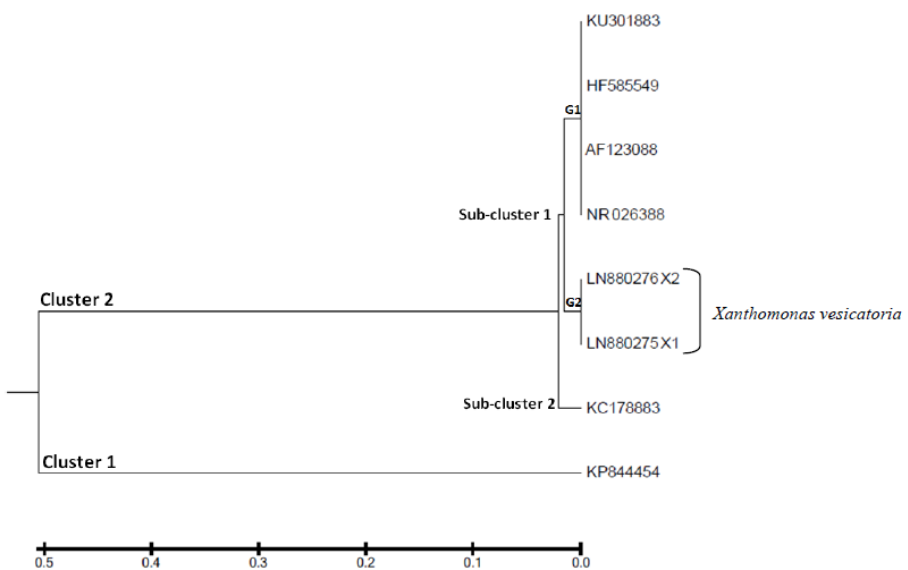

Figure 12 Phylogenetic tree of Xanthomonas vesicatoria (X1 and X2 isolates) obtained in this study and validly related bacteria from the alignment of $16 \mathrm{~S}$ rRNA sequences. The scale appearing at the bottom indicates linkage distance.

\section{DISCUSSION}

Characterization of the population structure, diversity, and evolution are the main factors for understanding the pathogen biology and providing information necessary for the development of effective means for disease control (Vancheva et al., 2018). Results of the pathological behaviors of the isolated tomato seedborne bacteria, their cultural, morphological and physiological characters, as well as molecular techniques (16S rRNA gene sequence) were indicated that Pantoed ananatis was associated with graywall symptoms (Stall et al., 1970), Pseudomonas syringae pv. tomato was the causal agent of bacterial speck disease and Xanthomonas vesicatoria was associated with bacterial spot disease (AbdAlla and Bashandy, 2008; Milijasevic etal., 2009 and Opara and Odibo 2009; Kolomiets et al., 2017; Roach et al., 2018).

Re-isolation of artificially infected tomato plants indicated that P.ananatis was an endophytic seed-borne bacteria, these results were consistent with findings of Rijavec et al., (2007), while previous results were in contrast with Cota et al., (2010). Whereas re-isolation of Ps.syringae pv. tomato from seeds proved that it's an epiphytic seed-borne. These results were matched with findings of Hirano and Upper, (2000), while it's were in disagreed with Ferrando et al., (2012) Results discovered that X.vesicatoria was an epiphytic and endophytic seedborne, these results were fixed with Kniskern et al., (2007).

Fatty acids profiling is a useful tool for identification and classification of plant pathogenic bacteria. It is potentially an extremely powerful predictive tool (Stead 1992 and Weller et al. 2000). Isolates of P.ananatis were distinguished by the ratios of fatty acids (12:0,14:0 and 18:0), that similarly mimics to the findings of Nischwitz et al., (2007). As well as, isolates of Ps. s. pv. tomato were distinguished by the ratios of fatty acids (14:0 and 16:1), that similarly mimics to the findings of Denny, (1988). In case of isolates of $X$. c. pv. vesicatoria were distinguished by the ratios of fatty acids (14:0, 15:0 and 16:0), that similarly corresponded with Vauterin et al., (1996) and Obradovicet al., (2004).
The use of 16S rRNA gene sequences to study bacterial phylogeny and taxonomy has been by far the most common housekeeping genetic marker (Ashmawy et al , 2020). 16S rRNAgene was used to identify the tested isolates and study the genetic variability among 3 isolates of Pantoea spp., 2 isolates of Pseudomonas spp. and 2 isolates of Xanthomonas spp. Results obtained of all tested isolates gave one band in the right expected molecular length. DNA sequences of tested isolates revealed that the sequences belong to P.ananatis, $P$. syringae pv. tomato and $X$. campestris pv. vesicatoria. Such findings agreed with data obtained with Krawczyket al., (2010) and Mbegaet al., (2012).

The bacterium associated with the tomato (Solanum esculentum) and the alternative host black nightshade ( $S$. nigrum) seeds appeared to be $P$. ananatis on the basis of $16 \mathrm{~S}$ rRNA gene sequence. This apparently is the first report of $P$. ananatis as a bacterial pathogen isolated from tomato and black nightshade seeds in Egypt. Alternative hosts such as several crop and weed species have been suspected to potentially play a role in the spread or survival of bacterial diseases (Ocimati et al., 2018). The current study determined the potential risk posed by black nightshade (S. nigrum) as alternative hosts to $P$. ananatis.

\section{REFERENCES}

Abdalla, M. E. (2000). Detection and identification of seed-borne pathogenic bacteria of imported tomato seeds in Egypt. EPPO Bulletin, 30(2), 327-331. https://doi.org/10.1111/j.1365-2338.2000.tb00904.x

Abd-Alla, M. H. (2008). Bacterial wilt and spot of tomato caused by Xanthomonas vesicatoria and Ralstonia solanacearum in Egypt. World Journal of Microbiology and Biotechnology, 24(2),

291-292

https://doi.org/10.1007/s11274-007-9385-8

Ashmawy, N. A., Jadalla, N. M., Shoeib, A. A., \& El-Bebany, A. F. (2015) Identification and genetic characterization of Pectobacterium spp. and related Enterobacteriaceae causing potato soft rot diseases in Egypt. J. Pure Appl. Microbiol, 9(3), 1847-1858

Ashmawy, N. A., El-Bebany, A. F., Shams, A. H., \& Shoeib, A. A. (2020). Identification and differentiation of soft rot and blackleg bacteria from potato using nested and multiplex PCR. Journal of Plant Diseases and Protection 127,141-153. https://doi.org/10.1007/s41348-019-00257-1

AL-Saleh, M. A. (2011). Pathogenic variability among five bacterial isolates of Xanthomonas campestris pv. vesicatoria, causing spot disease on tomato and their response to salicylic acid. Journal of the Saudi Society of Agricultural Sciences, 10(1), 47-51. https://doi.org/10.1016/j.jssas.2010.08.001

Boyle, J. S. (1994). Abnormal ripening of tomato fruit. Plant disease, 78(10), 936-944.

Brady, C. L., Venter, S. N., Cleenwerck, I., Engelbeen, K., Vancanneyt, M., Swings, J., \& Coutinho, T. A. (2009). Pantoea vagans sp. nov., Pantoea eucalypt sp. nov., Pantoea deleyi sp. nov. and Pantoea anthophila sp. nov. International journal of systematic and evolutionary microbiology, 59(9), 2339-2345. https://doi.org/10.1099/ijs.0.009241-0

Brenner, W. G., Romanov, G. A., Köllmer, I., Bürkle, L., \& Schmülling, T. (2005). Immediate-early and delayed cytokinin response genes of Arabidopsis thaliana identified by genome-wide expression profiling reveal novel cytokininsensitive processes and suggest cytokinin action through transcriptional cascades. The Plant Journal,44(2), 314-333. https://doi.org/10.1111/j.1365313X.2005.02530.x

Cota, L. V., Costa, R. V., Silva, D. D., Parreira, D. F., Lana, U. G. P., \& Casela C. R. (2010). First report of pathogenicity of Pantoea ananatis in sorghum (Sorghum bicolor) in Brazil. Australasian Plant Disease Notes, 5(1), 120-122.

Coutinho, T. A., \& Venter, S. N. (2009). Pantoea ananatis: an unconventional plant pathogen. Molecular plant pathology, 10(3), 325-335. https://doi.org/10.1111/j.1364-3703.2009.00542.x

Delétoile, A., Decré, D., Courant, S., Passet, V., Audo, J., Grimont, P., ... \& Brisse, S. (2009). Phylogeny and identification of Pantoea species and typing of Pantoea agglomerans strains by multilocus gene sequencing. Journal of clinical microbiology, 47(2), 300-310.

Denny, T. P. (1988). Phenotypic diversity in Pseudomonas syringae pv. tomato. Microbiology, 134(7), 1939-1948. https://doi.org/10.1099/00221287 $\underline{134-7-1939}$

El-meneisy, A.Z A. (2005).Studies on foliar bacterial diseases of tomato. M.Sc thesis, Faculty of Agriculture, Ain Shams University, 132 pp.

Fao, 2018. FAOSTAT statistical database. Rome. (available at http://faostat.fao.org).

Ferrando, L., Mañay, J. F., \& Scavino, A. F. (2012). Molecular and culturedependent analyses revealed similarities in the endophytic bacterial community composition of leaves from three rice (Oryza sativa) varieties. FEMS microbiology ecology,80(3), 696-708. https://doi.org/10.1111/j.1574 6941.2012.01339.x

Gitaitis, R. D., Chang, C. J., Sijam, K., \& Dowler, C. C. (1991). A differential medium for the semiselective isolation of Xanthomonas campestris pv vesicatoria and other cellulolytic xanthomonads from various natura sources. Plant disease, 75(12), 1274-1278. 
Gitaitis, R., \& Walcott, R. (2007). The epidemiology and management of seedborne bacterial diseases. Annu. Rev. Phytopathol., 45, 371-397. https://doi.org/10.1146/annurev.phyto.45.062806.094321

Gore, J. P., \& O'Garro, L. W. (1999). Xanthomonas campestris pv. vesicatoria from bell pepper and tomato in Barbados undergoes changes in race structure, virulence and sensitivity to chemical control agents. Journal of Phytopathology, 147(7-8), 397-402. $\quad$ https://doi.org/10.1111/j.14390434.1999.tb03840.x

Goszczynska, T., Moloto, V. M., Venter, S. N., \& Coutinho, T. A. (2006) Isolation and identification of Pantoea ananatis from onion seed in South Africa. Seed Science and Technology, 34(3), 655-668. https://doi.org/10.15258/sst.2006.34.3.12

Goszczynska, T., Venter, S. N., \& Coutinho, T. A. (2006). PA 20, a semiselective medium for isolation and enumeration of Pantoea ananatis. Journal of microbiological methods, 64(2)

$225-231$ https://doi.org/10.1016/j.mimet.2005.05.004

Hirano, S. S., \& Upper, C. D. (2000). Bacteria in the leaf ecosystem with emphasis onPseudomonas syringae - a pathogen, ice nucleus, and epiphyte. Microbiol. Mol. Biol. Rev., 64(3), 624-653.

Kates, M. (1972).Techniques of lipidology. North-Holland/American Elsevier, P. 351

Kniskern, J. M., Traw, M. B., \& Bergelson, J. (2007). Salicylic acid and jasmonic acid signaling defense pathways reduce natural bacterial diversity on Arabidopsis thaliana. Molecular plant-microbe interactions, 20(12), 1512-1522. https://doi.org/10.1094/MPMI-20-12-1512

Kumar, S., Stecher, G., \& Tamura, K. (2016). MEGA7: molecular evolutionary genetics analysis version 7.0 for bigger datasets. Molecular biology and evolution, 33(7), 1870-1874. https://doi.org/10.1093/molbev/msw054

Kolomiets, J. V., Grygoryuk, I. P., \& Butsenko, L. M. (2017). Bacterial diseases of tomato plants in terms of open and covered growing of Ukraine. Annals of Agrarian Science, 15(2), 213-216. https://doi.org/10.1016/j.aasci.2017.05.010

Krawczyk, K., Kamasa, J., Zwolinska, A., \& Pospieszny, H. (2010). First report of Pantoea ananatis associated with leaf spot disease of maize in Poland. Journal of Plant Pathology, 807-811.

Manjula, C. P., Kumar, M. K. P., \& Basha, C. R. J. (2017). Studies on variations among prevailing races of Xanthomonas vesicatoria causing bacterial spot of tomato in Karnataka. Journal of Mycopathological Research, 54(4), 503-510.

Mbega, E. R., Wulff, E. G., Mabagala, R. B., Adriko, J., Lund, O. S., \& Mortensen, C. N. (2012). Xanthomonads and other yellow-pigmented Xanthomonas-like bacteria associated with tomato seeds in Tanzania. African Journal of Biotechnology, 11(78), 14297-14304. https://doi.org/10.5897/AJB12.1305

Meguire, R. G., Jones, J. B., \& Sasser, M. (1986). Tween media for semiselective isolation of Xanthomonas campestris pv. vesicatoria from soil and plant material. Plant Disease, 70, 887-889.

MILIJAšEvIć, S., TODOROvIć, B. I. L. J. A. N. A., Rekanović, E., Potočnik, I., \& Gavrilović, V. (2009). Races and hosts of Pseudomonas syringae pv. tomato in Serbia. Archives of Biological Sciences, 61(1), 93-103. https://doi.org/10.2298/ABS0901093M

Nischwitz, C., Gitaitis, R., Sanders, H., Langston, D., Mullinix, B., Torrance, R., ... \& Zolobowska, L. (2007). Use of fatty acid methyl ester profiles to compare copper-tolerant and copper-sensitive strains of Pantoea ananatis. Phytopathology, 97(10), 1298-1304. https://doi.org/10.1094/PHYTO97-10-1298

Obradovic, A., Mavridis, A., Rudolph, K., Janse, J. D., Arsenijevic, M., Jones, J. B., ... \& Wang, J. F. (2004). Characterization and PCR-based typing of Xanthomonas campestris pv. vesicatoria from peppers and tomatoes in Serbia. European Journal of Plant Pathology, 110(3), 285-292.

Ocimati, W., Were, E., Groot, J. C., Tittonell, P., Nakato, G. V., \& Blomme, G. (2018). Risks posed by intercrops and weeds as alternative hosts to Xanthomonas campestris pv. musacearum in banana fields. Frontiers in plant science, 9, 1471. https://doi.org/10.3389/fpls.2018.01471

Opara, E. U., \& Odibo, F. J. C. (2009). Studies and characterization of Bacterial spot pathogen of Tomato Xanthomonas campestris pv. vesicatoria. Journal of Molecular Genetics, 1, 35-43.

Radwan, S. S. (1978). Coupling of two-dimensional thin-layer chromatography with gas chromatography for the quantitative analysis of lipid classes and thei constituent fatty acids. Journal of Chromatographic Science, 16(11), 538-542. https://doi.org/10.1093/chromsci/16.11.538

Rijavec, T., Lapanje, A., Dermastia, M., \& Rupnik, M. (2007). Isolation of bacterial endophytes from germinated maize kernels. Canadian journal of microbiology, 53(6), 802-808. https://doi.org/10.1139/W07-048

Roach, R., Mann, R., Gambley, C. G., Shivas, R. G., \& Rodoni, B. (2018) Identification of Xanthomonas species associated with bacterial leaf spot of tomato, capsicum and chilli crops in eastern Australia. European Journal of Plant Pathology, 150(3), 595-608. https://doi.org/10.1007/s10658-017-1303-9

Şahİn, F. (2001). Severe outbreak of bacterial speck, caused by Pseudomonas syringae pv. tomato, on field-grown tomatoes in the eastern Anatolia region of Turkey. Plant pathology, 50(6). http://dx.doi.org/10.1046/j.1365-
Shenge, K. C., Mabagala, R. B., \& Mortensen, C. N. (2010). Current status of bacterial-speck and-spot diseases of tomato in three tomato-growing regions of Tanzania. Journal of Agricultural Extension and Rural Development, 2(5), 84-88. Shin, G. Y., Schachterle, J. K., Shyntum, D. Y., Moleleki, L. N., Coutinho, T. A., \& Sundin, G. W. (2019). Functional Characterization of a Global Virulence Regulator Hfq and Identification of Hfq-Dependent sRNAs in the Plant Pathogen Pantoea ananatis. Frontiers in microbiology, 10, 2075. https://doi.org/10.3389/fmicb.2019.02075

Stall, R., Alexander, L., \& Hall, C. (1970). Effect of tobacco mosaic virus and bacterial infections on occurrence of graywall of tomato[Erwinia ananas]. Proceedings of the Florida State Horticultural Society, 1969, 82, 157 61.

Stead, D. E. (1992). Grouping of plant-pathogenic and some other Pseudomonas spp. by using cellular fatty acid profiles. International Journal of Systematic and Evolutionary Microbiology, 42(2), 281-295. https://doi.org/10.1099/00207713$\underline{42-2-281}$

Vauterin, L., Yang, P., \& Swings, J. (1996). Utilization of fatty acid methyl esters for the differentiation of new Xanthomonas species. International Journal of Systematic and Evolutionary Microbiology, 46(1), 298-304. https://doi.org/10.1099/00207713-46-1-298

Vancheva, T., Stoyanova, M., Tasheva-Terzieva, E., Bogatzevska, N., \& Moncheva, P. (2018). Molecular methods for diversity assessment among xanthomonads of Bulgarian and Macedonian pepper. brazilian journal of microbiology, 49, 246-259. https://doi.org/10.1016/j.bjm.2017.08.011

Walterson, A. M., \& Stavrinides, J. (2015). Pantoea: insights into a highly versatile and diverse genus within the Enterobacteriaceae. FEMS Microbiology Reviews, 39(6), 968-984. https://doi.org/10.1093/femsre/fuv027

Weller, S. A., Elphinstone, J. G., Smith, N. C., Boonham, N., \& Stead, D. (2000) Detection of Ralstonia solanacearumstrains with a quantitative, multiplex, realtime, fluorogenic PCR (TaqMan) assay. Appl. Environ. Microbiol., 66(7), 28532858

Yahiaoui-Zaidi, R., Jouan, B., \& Andrivon, D. (2003). Biochemical and molecular diversity among Erwinia isolates from potato in Algeria. Plant pathology, 52(1), 28-40. https://doi.org/10.1046/j.1365-3059.2003.00791.x 